\title{
DIGITALCOMMONS
}

@WAYNESTATE -

Wayne State University

$12-1-2013$

\section{Jewish genetic origins in the context of past historical and anthropological inquiries}

John M. Efron

University of California-Berkeley

\section{Recommended Citation}

Efron, John M., "Jewish genetic origins in the context of past historical and anthropological inquiries" (2013). Human Biology Open Access Pre-Prints. Paper 42.

http://digitalcommons.wayne.edu/humbiol_preprints/42

This Open Access Preprint is brought to you for free and open access by the WSU Press at DigitalCommons@WayneState. It has been accepted for inclusion in Human Biology Open Access Pre-Prints by an authorized administrator of DigitalCommons@WayneState. 
John M. Efron

Koret Professor of Jewish History

University of California-Berkeley

"Jewish genetic origins in the context of past historical and anthropological inquiries"

Abstract The contemporary study of Jewish genetics has a long prehistory dating back to the eighteenth century. Prior to the era of genetics studies of the physical makeup of Jews were undertaken by comparative anatomists and physical anthropologists. In the nineteenth century the field was referred to as "race science." Believed by many race scientists to be a homogeneous and pure race, Jews occupied a central position in the discourse of race science because they were seen as the control group par excellence to determine the relative primacy of nature or nurture in the development of racial characteristics. In the nineteenth century, claims of Jewish homogeneity prompted research that sought to explain morphological differences among Jews, chief among them, the difference between Sephardim and Ashkenazim. I examine some of these original debates here with a view to placing them in their historical and cultural contexts.

This issue of Human Biology deals with Jews and genetics and most of the articles appearing here are contributions from scientists working in that very lively and everexpanding field. But it would do us well to recall that science is situational, contingent, and part of culture. It is not separate from it and as such is a window onto a society, its mores and values. This also means that like art or music science can be examined in its social and historical context. Unlike most of the other contributors to this issue I am not a scientist but an historian and what I intend to discuss in this article are the origins of today's discourse about Jews and genetics. Specifically, I will discuss the anthropological discourse about Jews as it existed in the pre-genetic era. Today's research on Jews and their genes has a beginning and it is not of recent origin. In what 
follows I will discuss when and where such research began, who undertook it, what its themes were, and the social and intellectual currents that informed such research.

\section{Eighteenth-Century Origins}

The discourse about the physical nature of the Jewish people began in the eighteenth century and was, in essence, rooted in the emerging discipline of physical anthropology, which, over the course of the nineteenth century became known as "race science" (Hannaford 1996; Mühlmann 1968). Our story begins in Germany because that is where the modern discipline of physical anthropology was born. Most crucially for us it emerged at exactly the same time that Germans were deeply immersed in debates over whether or not to grant the Jews legal emancipation. Briefly put, the process of emancipating the Jews of Germany, that is to say removing the myriad special taxes, as well as occupational, educational, residential and even marital restrictions culminating in the granting of citizenship, was a long and uneven one that saw the Jews on Prussia first emancipated in 1812 , that being rescinded in 1815 , a brief liberalizing trend that came in the wake of the 1848 revolutons and then with the conservative reaction to those events, emancipation was again rescinded in 1850. For the most part Germany's Jews were emancipated with the unification of Germany and the founding of the Second Reich in 1871. There remained a few areas of upper civil service employment that remained off limits to Jews and those restrictions were finally done away with the advent of the Weimar Republic in 1919. Emancipation was finally revoked in the most brutal way by the Nazis. 
Historians consider the whole process in Germany in terms of a contract in which Jews were emancipated piecemeal and conditionally. They were essentially told that in exchange for identifiable cultural change or "improvement" they would be emancipated to a certain extent with further gains to be granted as a reward for further change (Mosse 1995). The problem, of course, was that the goal posts kept being shifted and Jews never had a really good sense of when they had achieved the transformations demanded of them. By contrast, in France, Jews were emancipated with the Revolution and while the French held an equally dim view of Jews, their faith in the Enlightenment ideology that held that all people were capable of change and improvement, was sufficiently strong, that they had faith that history and the new environment in which Jews were free, would lead to their becoming Frenchmen (Hyman 1998). Those non-Jews who who favored emancipation proceded from the assumption that the Jews were a degraded people but were like this because of the way that Christian society had treated them. If the social conditions under which they suffered were ameliorated, then, it was held, Jews would respond accordingly and become productive, healthy, upright citizens. In Germany, which had no liberal revolution and where French Enlightenment ideas and ideals did not strike deep roots, there was far greater skepticism about the capacity of Jews to chnage. Opponents of emancipation held that irrespective of the way they were treated Jews were inherently different and emancipating them would not change the fact that they could never become European, while other more extreme views held that not only was metamorphosis impossible but that the Jews actually posed a danger to Germans.

It is against this background that physical anthropologists turned their attention toward the Jews. When Jews first came under scientific scrutiny in the eighteenth 
century, it was not entirely clear to which race the Jews belonged. For some scientists they were white, others considered them black or at least white with "negroidal" features, while many more classified them as Asiatic (Efron 1994). In the eighteenth century anthropologists and biologists initially concerned themselves with the task of human classification — to simply take stock of human racial diversity. Soon, however, they sought to explain the reasons for human difference. Johann Friedrich Blumenbach (1752-1840), one of the founding figures of physical anthropology, believed that there were five major groups or races and classified them according to color. These were Caucasian (white), Mongolians (yellow), Ethiopians and all other dark complexioned peoples (black), Americans (copper), Malay (tawny). Homo sapiens, he said, had originated in the Caucasus and human difference was the result of degeneration from the original human type - the Caucasian. The further away from the Caucuses a people ended up settling the greater their degeneration and hence their difference from the original Caucasians (Blumenbach 1865).

With this, Blumenbach, a liberal, man of the Enlightenment, rejected any notion of permanent racial characteristics and instead, held that differences in human appearance were conditioned by climate and diet, and those qualities were susceptible to alteration when geographic relocation had occurred. "Unless I am mistaken," he wrote, "there are instances of peoples who after they have changed their localities and have migrated elsewhere, in the process of time have changed also their original form of countenance for a new one, peculiar to the new climate." But in turning his attention to Jews Blumenbach observed that they were an exception to the rules of nature. Their wide geographic dispersion notwithstanding, different environments had been unable to effect 
a change in Jewish appearance: "Above all, the nation of the Jews who, under every climate, remain the same as far as the fundamental configuration of [the] face goes, [are] remarkable for a racial character almost universal, which can be distinguished at the first glance even by those little skilled in physiognomy, although it is difficult to limit and express by words." (Blumenbach 1865) Blumenbach was a deeply learned man, a scientist of great renown and yet he, a professor of medicine at the University of Göttingen, was at a loss to explain what he imagined he saw when studying the physical features of Jews. Socially, occupationally, religiously and culturally exceptional in every way, Jews, it seemed, were physiologically distinct as well.

Could it be really true that all peoples were subject to physiological change except the Jews? According to other comparative anatomists, the unalterability of the Jews had to do with their peculiar anatomy. In 1812, a Dutch physician studying the skull of a thirty-year-old Jewish man noted the peculiarly "large nasal bones," the "square chin," and the specifically Jewish "bony impressions on both sides of the lateral orbits." This, he argued, was due to the fact that "among Jews, the muscles primarily used for talking and laughing are of a kind entirely different from those of Christians." In 1812 the Berlin anthropologist Karl Asmund Rudolphi remarked on the consistency of Jewish physical features, characteristics that set them apart from the European majority: "Under Julius Caesar [the Jews] were almost as deeply rooted in Rome as they are today in some states of Germany and in Poland, and in a word, have become indigenous.... [But] their form has not changed. Their color is here lighter, there darker, but their face, their skulls everywhere have a peculiar character." (Efron 1994) 
Where simply describing and classifying Jews was the aim of eighteenth century physical anthropology, over the course of the nineteenth century, the subject became far more complex and multi-faceted. The field itself underwent a name change and became known as "race science." Race was the principle category of large-scale analysis of human characteristics prior to the advent of genetics. As it applied to Jews, race science focused upon accumulating anthropometric measurements in massive quantities in order to determine their physical and psychological characteristics (Auerbach 1907a; Hart 2000).

\section{Race Science and the Jews in the Nineteenth Century}

Jews were the focus of so much scientific attention when it came to the question of race because their very existence seemed to contemporary scientists (including Jewish ones), to provide a framework for questions to do with nature versus nurture. The basic structure of the argument went as follows: The Jews are a minority group with an ancient history and have been victims of sustained hatred and periodic violence for centuries. Nevertheless, they continue not only to survive, but also flourish. How have the Jews been able to defy the will of history? All of the ancient civilizations had disappeared. The Egyptians, Babylonians, Assyrians, Greeks, Romans and Persians were no more. All, that is, except the Jews. Based on this erroneous yet widely believed schema, anthropologists asked whether the key to Jewish survival had been their ability to adapt to any environment in which they found themselves, or was their tenacity derived from their particular racial qualities? (Judt 1903) 
The debate over the physical nature of Jewishness revolved around a) determining whether the Jews were composed of one or more racial types, and how those types had arisen. Among those types were Sephardic, Ashkenazic, Yemenite, Ethiopian, and Indian Jews; and b) whether Jews displayed pathological and psychological features which were indeed peculiar to them as Jews (Efron 2001). (In the interests of space, I shall only be dealing with the first set of question in this essay). In highly modified form these are precisely the kinds of questions modern geneticists still work. But more than this, the notion that there is a Jewish gene or that certain population groups are of Jewish origin animate both scientific attention and popular fascination. The reactions of the scientific establishment and the general public to what contemporaries called the "Jewish racial question" in the nineteenth century and those of the same groups to contemporary findings is remarkably similar. The reason has to do with the fact that answers to these questions remain as unsettled as they were over a century ago. Whether it is claims that link the Lemba of Southern Africa with Jews, the still hotly contested origins of Ashkenazic Jews and the possible conversion of the Khazars of the Black Sea region, or identifying those populations whose Y chromosome, which appears to be a signature element of the Cohanim or the ancient Jewish priesthood, scientists and the general public remain fascinated by Jewish origins and the diversity of Jewish morphology. And the fact is that the demand for such information is greater than ever before. Whereas such work, in its earliest phase at the end of the nineteenth century, was confined to scientific journals, now anthropology and genetics journals have been joined by serious but popular publications that are accessible and intelligible to the general public. There is also no shortage of books written from a religious standpoint as opposed to a scientific 
one, which seek to trace the lineage of the Jews. There are websites dedicated to these questions and even television documentaries such as the NOVA special on the "Ten Lost Tribes," are supplemented by the regular appearance of new books on this subject (Shtull-Trauring 1996; Parfitt 2000; Gonen 2002; Halkin 2002; Brook 2003; Asa-El 2004; Hansen 2009; Ben-Dor Benite 2009). To give but one example of the latter, a book that first appeared in 1892 on the Ten Lost Tribes, which claimed that they ended up in the British Isles was recently re-published in 2012. Very few books that are not categorized as "classics" enjoy that kind of longevity but it is testament to the popularity and importance of this subject (Howlett 2012). Geneticists working on this and allied subjects would do well to at least be aware of the long-lived interest in and cultural significance of the work that they do, be aware of its history and its cultural meaning.

\section{Jewish Racial Characteristics}

The question of Jewish racial origins and especially the proposition of Jewish racial purity (a central issue in the nineteenth century) was the most hotly debated issue among race scientists who studied the Jews. As a demographically small population that scrupulously practiced endogamous marriage, it was widely assumed that Jews bore no physical features, drawn from foreign admixture. However, the main question for anthropology was, if Jews had never mixed with other peoples, how could one account for the fact that not all Jews looked alike? If Jews were racially Semites (a deeply problematic designation because it was a linguistic and not an anthropological category), and had remained pure, and Semites were said to be dark haired, dark complexioned peoples with a certain head shape, how had there arisen blue-eyed, blond Jews, red- 
headed Jews, and virtually all manner of combinations? (Auerbach 1907b) Were these physical variations the product of environmental adaptation, or were the premises of Jewish anthropology incorrect, and had Jews actually mixed with others? If so, at what point in their long history did Jews mix with non-Jews to produce racial divergencies from the Semitic norm? To answer these questions history became the handmaiden of physical anthropology and such studies, which were published in the most prestigious scientific journals of the day, were a blend of speculative history and statistical analysis (Hart 2011).

These were not merely the questions of science. They were also questions of politics. If the Jews had mixed with non-Jews, the questions were - When and Where? Had racial mixture occurred in ancient Palestine, meaning the Jews were never a pure race, even in the time of political independence, or had race-crossing taken place during their long period in Exile? (Alsberg 1891). And if mixing had taken place, which Jews had mixed with non Jews. All Jewish communities or just some? The political ramifications of such questions, at a time when all Europeans were obsessed with race, racial purity, and national origins were extremely important (Poliakov 1977). This was also not just a matter of non-Jewish anthropologists addressing these questions but we see the emergence in the nineteenth century of Jewish anthropologists, who set about writing a biological history of the Jewish people to solve these and other problems.

The methodological basis of race science was statistical analysis and descriptions of Jewish physicality were likewise based on large scale statistical surveys and anthropometrics, the measurement of bodily parts. Of all the parts of the body that were subjected to anthropometric measurement, the skull was by far the most important (Gould 
1996). The primary reason for this was that contemporary anthropological theory postulated that the skull was the most stable racial characteristic, retaining its size and shape, impervious to the influences of environmental change or social and sexual selection. Thus, changed head form was thought to only occur with racial miscegenation. To give but one example of this thorny problem as it pertained to Jews, in England, an Australian Jew named Joseph Jacobs was one of the pre-eminent researchers into Jewish racial characteristics. (Efron 1994) In a presentation he made to the Royal Anthropological Institute of Great Britain in 1885 Jacobs addressed the crucial subject of skull shape, reporting that based upon 120,000 craniometric measurements of Jews, they were predominantly brachycephalic (round-headed) (Jacobs 1891).

Jacobs's characterization of Jewish skull shape was widely supported by other craniometrists. Nevertheless, for those like Jacobs who subscribed to a theory of Jewish racial purity, the present-day brachycephalism of the Jews required explanation. For if modern Jews were directly descended from the ancient Hebrews, and they were Semites, why then did modern Jews not display the same dolicocephalic (long-headed) characteristics as other modern day Semites, such as Arabs or Sephardic Jews? The puzzle was to explain how changed head-form, without racial admixture, had taken place. There were two possible answers: perhaps modern Jews were not purely Semitic and had intermarried on a large scale, or perhaps the ancient Hebrews were themselves brachycephalic. The distinguished German anthropologist Felix von Luschan maintained that the brachycephalism seen in modern Jews was the result of large-scale intermarriage between ancient dolicocephalic Hebrews and brachycephalic Hittites (Von Luschan 1892). 
Jacobs dismissed the theory of head-form stability, maintaining that

environmental and social forces could effect cranial divergence from an original type.

Sensing that the debate was of broader significance to science, Jacobs made a claim for

the universal instructiveness and applicability of Jewish anthropology:

But the point in the discussion seems to me to raise a problem of exceeding interest within the anthropological sphere itself. Professor Ripley [a professor at MIT and Columbia and author of one of the most widely cited race science texts of the nineteenth century] assumes that round heads beget round heads, and long heads descend from long heads for all time unchanged. That appears to carry with it the assumption that no amount of brain activity can increase the mass of the brain, that skull capacity has no relation to mental capacity, and that alone among the organs of the body the brain and skull are incapable of growth, change, or development. The crux of Jewish anthropology raises this problem, as I shall proceed to show, and, if I have interpreted history aright, offers valuable material toward its solution (Jacobs 1899; Ripley 1899).

Jacobs argued that "in races where progress depends upon brain rather than

muscle the brain-box broadens out as a natural consequence." Jacobs explained himself

in purely Lamarckian terms, noting that:

[t]he application of all this to the case of the Jews seems obvious. If they had been forced by persecution to become mainly blacksmiths, one would not have been surprised to find their biceps larger than those of other folk; and similarly, as they have been forced to live by the exercise of their brains, one should not be surprised to find the cubic capacity of their skulls larger than that of their neighbours."

Here we have a case where biology and historical explanation come together to form an anthropological argument that supports the notion of Jewish racial purity from a liberal perspective in that it rejects notions of the permanency of racial characteristics and gives primacy to environmental determinism.

\section{The Sephardic-Ashkenazic Split}


Let us now examine at some length the work of William Z. Ripley (1867-1941), to whom Jacobs refers. He was a leading student of race in the nineteenth century and author of The Races of Europe, one of the most important and influential works of its kind. In looking at Ripley on Jews we will see a contrary view to the one expressed by Jacobs. Ripley rejects the notion of Jewish racial purity and yet nevertheless argues for the distinctiveness of Jewish physical traits.

At the center of Ripley's argument lies the discourse on Sephardic and Ashkenazic Jews. The anthropological importance of these two groups lay in the fact that their diverse morphological presentation constituted one of the great conundrums and challenges for race science. But an examination of the split also promised to unlock the mystery of the origins of the Jewish people and for some Christian scientists the study of both groups even promised to shed light on Jesus's bodily form and appearance and possible racial provenance. Ripley addressed Jews at length in The Races of Europe and we will examine his arguments in some detail, beginning by quoting the section on the Sephardic-Ashkenazic split in full for it gives a sense of what constituted race science at the turn of the twentieth century:

Tradition has long divided the Jewish people into two distinct branches: the Sephardim or southern, and the Ashkenazim, or north European. Mediaeval legend among the Jews themselves traced the descent of the first from the tribe of Judah; the second, from that of Benjamin.... Early observers all describe these two branches of the Jews as very different in appearance. [Carl] Vogt in his Lectures on Man [1864] assumes the Polish type to be descended from Hindu sources, while the Spanish alone he held to be truly Semitic. Weisbach gives us the best description of the Sephardim Jew [sic] as to-day found at Constantinople. He is slender in habit, he says; almost without exception the head is "exquisitely" elongated and narrow, the face a long oval; the nose hooked and prominent, but thin and finely chiselled; hair and eyes generally dark, sometimes, however, tending to a reddish blond. This rufous tendency in the Oriental Jew is emphasized by many observers. Dr. Beddoe found red 
hair as frequent in the Orient as in Saxon England, although later results do not fully bear it out. This description of a reddish Oriental type corresponds certainly to the early representations of the Saviour; it is the type, in features perhaps rather than hair, painted by Rembrandt - the Sephardim in Amsterdam being familiar to him, and appealing to the artist in preference to the Ashkenazim [sic] type. This latter is said to be characterized by heavier features in every way. The mouth, it is alleged, is more apt to be large, the nose thickish at the end, less often clearly Jewish perhaps. The lips are full and sensual, offering an especial contrast to the thin lips of the Sephardim. The complexion is swarthy oftentimes, the hair and eyes very constantly dark, without the rufous tendency which appears in the other branch. The face is at the same time fuller, the breadth corresponding to a relatively short and round head. Does this contrast of the traditional Sephardim and Ashkenazim facial types correspond to the anthropometric criteria by means of which we have analyzed the various populations of Europe? And, first of all, is there the difference of head form between the two which our descriptions imply? And, if so, which represents the primitive Semitic type of Palestine? The question is a crucial one. It involves the whole matter of the original physical derivation of the people, and the rival claims to purity of descent of the two branches of the nation. (Ripley 1899).

Ripley then went on to demonstrate, on the basis of copious craniometric data, that Sephardim and Ashkenazim were more alike in head shape than science had previously considered, and concluded that "the Jews wherever found in Europe betray a remarkable similarity in head form, the crania being considerably broader than among the peoples of Teutonic descent..... More important still, they seem to be generally very closely akin in head form to the people among whom they reside" (Ripley 1899). The consequences of this assessment were of great significance. For Ripley, the modern day Arab had remained true to the original Semitic type, that is long-headed, and Jews had deviated widely from that. This could only mean two things as far as Ripley was concerned: "either the great body of the Jews in Europe to-day certainly all the Ashkenazim, who form upward of ninety per cent of the nation, and quite probably the Sephardim also, except possibly those in Africa have departed widely from the parental 
type in Palestine; or else the original Semitic type was broad-headed, and by inference distinctly Asiatic in derivation; in which case it is the modern Arab which has deviated from its original pattern." Ripley opted for the first option, believing that Jews had deviated from the original Semitic head shape and thus, "the boasted purity of descent of the Jews is, then, a myth" (Ripley 1899)

So the Jews, whether Ashkenazim or Sephardim, bore cranial indexes that were similar to those of their neighbors. Ripley posited that large-scale conversions of pagans to Judaism in the first centuries after Jesus and illicit marriages in the Middle Ages explained the admixture of non-Semitic physical traits to the Jewish population. And yet Ripley firmly believed in the distinctiveness and easy identifiablity of the Jews and pointed to four features that he thought made the Jews what they were in physical terms. Along with head shape, which he held to be most important criterion of racial analysis, Ripley also focused hair color, shape of nose, appearance of the eyes, and shape of the lips.

Ripley's four categories were essentially found on the head and about the face. He began at the top, with hair color, and noted that "science corroborates the popular impression that the modern Jews are distinctively of a brunet type. This constitutes one of the principal traits by which they may be almost invariably identified" (Ripley 1899). The nose constituted the second most important facial feature associated with Jews and Ripley, reporting on the research of other scientists, addressed the common perception that there was a peculiarly Jewish "humped or hook" nose but concluded that statistics of nasal indexes did not bear this out. Undeterred that the numbers did not confirm popular opinion Ripley found a way out and a means by which to assert Jewish nasal and thus 
physical distinctiveness. "Visual impressions," he wrote, "will also confirm our deduction. The Jewish nose is not so often truly convex [hooked] in profile. Nevertheless, it must be confessed that it gives a hooked impression. This seems to be due to a peculiar 'tucking up of the wings,' as Dr. Beddoe expresses it. [Jacobs refered to it as 'nostrility'] (Jacobs 1891). Herein lies the real distinctive quality about it, rather than in any convexity of outline. In fact, it often renders a nose concave in profile, immediately recognisable as Jewish" (Ripley 1891) It was Ripley's visual impression that that even if not actually hooked, the nose seemed to look hooked, and thus it was distinctively Jewish. When Ripley could not confirm the popular prejudices to which he was heir by appeal to scientific measurements, those prejudices still prevailed in his analysis, seemingly buttressed by vague impressions and aesthetic judgements.

Physical anthropologists were notorious splitters and disagreed incessantly. So, for, example, the famous German geographer, Richard Andree, author of a widely cited race science text on the Jews, refused to lump Ashkenazim and Sephardim together. $\mathrm{He}$ distinguished the latter who "almost without exception are beautiful, slender, albeit narrow-shouldered, with exquisite, narrow heads," their "finely chiseled noses make it easy to identify the noble Spanish Jews" (Andree 1881).

For race scientists no less than poets the eyes were believed to be a window onto the soul and much could be read into the ocularity of the Jews. For Ripley, their "lids are rather full, the eyes large, dark, and brilliant. A general impression of heaviness is apt to be given. In favourable cases this imparts a dreamy, melancholy, or thoughtful expression to the countenance; in others it degenerates into a blinking, drowsy type; or, again, with eyes half closed, it may suggest suppressed cunning." Finally arriving at the bottom of the face Ripley observed, "quite persistent also is a fulness of the lips, often 
amounting in the lower one almost to a pout. The chin in many cases is certainly rather pointed and receding" (Ripley 1899)

Ripley's heavily numerical descriptions of Jews, replete with biometric maps, charts, tables, and graphs appeared very different from the more purely descriptive physical anthropology texts of the eighteenth century. But at the end of the day, the position of Ripley, a Boston Brahmin, and racist, was really no different from that of Blumenbach, the enlightened liberal. For both men "the nation of the Jews...can be distinguished at the first glance even by those little skilled in physiognomy."

Where Ripley elided Sephardim and Ashkenazim the split between the two groups was far more definitve and meaningful for Jewish race scientists. What we see among them is a process of Sephardic idealization that crossed the line into a myth about Sephardic superiority. In brief, in the nineteenth century, German Jewry in particular but among other Jewish communities as well, there was a veritable cult of the Sephardic Jews, whose culture, social status, and overall achievements, made them appear as an ideal Jewish community and German Jewry saw the medieval Jews of Spain (Sepharad in Hebrew and hence the term Sephardim) as an excellent model for their own project of acculturation. Especially appealing was the fact that the success the Jews of the Iberian Penisula enjoyed did not come at the cost of their Judaism. Under Islam, it was said, the Jews were able to combine a level deep acculturation with a staunch adherence to Judaism. The lionization of the Sephardic Jews was, ironically, a myth largely of Ashkenazic making, including Ashkenazic scientists, for whom the Sephardim represented the superior Jewish racial type. The Ashkenazic myth of Sephardic supremacy was the product of fin-de-siècle anxieties about the aesthetics of Jewish 
manhood, anxieties generated by a cultural universe informed by competing nationalisms, racial tensions and intense antisemitism (Efron forthcoming).

The rise of the antisemtic movement at the end of the nineteenth century saw the development of an elaborate liturgy of Jew hatred that charged the Jews as being aggressive conspirators, whether sexual predators, rapacious capitalists, or Bolshevik revolutionaries. At the same time, another image of the Jewish male emerged at the end of the nineteenth century, one that was in many ways the exact opposite of the Jew as threatening menace. In this version he was effete, delicate, unmanly, lacking in valor and decidedly unathletic — the very opposite of the era's obession with virility and masculinity. With the rise of mass culture these images of the weak Jewish male were spread far and wide. (Mosse 1996).

The cumulative impact of all this was an unending assault on the Jewish body, a body that was almost always Ashkenazic. By contrast, the Sephardic Jew was largely left unscathed, as he was held up as Jewish countertype. For Ashkenazim the Sephardim served as examples of beautiful, noble, and healthy Jews. Indeed, when the glowing anthropological descriptions of Sephardic Jews are compared to those of Ashkenazim, it can be seen that the Sephardi served as the equivalent of the Jewish 'Aryan,' a glorious figure, characterized by his nobility, breeding, poise, and creativity.

To provide just two examples of Ashkenazic descriptions of Sephardim that were dedicated to drawing a sharp distinction between the two groups and that entailed heavy doses of Ashkenazic self-abnegation we begin with an address to the Royal Anthropological Institute in 1885, by the distinguished Oxford scholar Adolf Neubauer (1831-1907). In the typical language of contemporary race science, Neubauer declared 
that there were " 1 st, those with a well-developed nose, black and striking eyes, and fine extremities -- in one word, the noble race of the Sephardim, or the Spanish-Portuguese Jews; 2nd, those who have a thickish nose, large mouth, and curled hair, features which are represented amongst the Ashkenazim, or the German-Polish Jews" (Neubauer 1885)

One of the cornerstones of race science in the pre-genetic era was its elevation of subjective notions of beauty and ugliness to legitimate scientific categories of classification. According to Maurice Fishberg, a prominent New York City physician and anthropological consultant to the Bureau of Immigration:

[The Sephardim] have generally black or brown hair, occasionally red and rarely blonde; large black or brown eyes, seldom grey, and rarely blue. In addition to their dark complexion, they are short of stature and either dolichocephalic or mesocephalic. The face is oval, the forehead receding, the eyes almond-shaped with the outer extremity very pointed, while the dark eyebrows are very bushy at the inner end, where they tend to unite over the root of the nose. The traditional Semitic beauty, which in women often assumes an exquisite nobility, is generally found among these Jews, and when encountered among Jews in Eastern or Central Europe is always of this type. Indeed, it is hard to imagine a beautiful Jewess, who looks like a Jewess, presenting any other physical type. (Fishberg 1911)

While the descriptions cited above no longer have a place in scientific or humanities discourse studies on Sephardim and Ashkenazim remain an area of significant interest in the field of Jewish genetics. If we simply look at the abstract of a well-known study on Sephardi and Mizrahi Jews conducted by Doron Behar and others, when the genetic references are taken away some of the terms and ideas we have encountered thus far (and I have highlighted them below) still appear. This is not to say that nothing has changed. It certainly has. However it is noteworthy that some of the fundamental questions first asked a century ago are still being posed and the use of Jewish history to help lay out the scientific propositions being tested still obtains. The article in question, 
"Counting the Founders: The Matrilineal Genetic Ancestry of the Jewish Diaspora"

begins thus:

The history of the Jewish Diaspora dates back to the Assyrian and Babylonian conquests in the Levant, followed by complex demographic and migratory trajectories over the ensuing millennia which pose a serious challenge to unraveling population genetic patterns. Here we ask whether phylogenetic analysis, based on highly resolved mitochondrial DNA (mtDNA) phylogenies can discern among maternal ancestries of the Diaspora. Accordingly, 1,142 samples from 14 different non-Ashkenazi Jewish communities were analyzed. A list of complete mtDNA sequences was established for all variants present at high frequency in the communities studied, along with high-resolution genotyping of all samples. Unlike the previously reported pattern observed among Ashkenazi Jews, the numerically major portion of the nonAshkenazi Jews, currently estimated at 5 million people and comprised of the Moroccan, Iraqi, Iranian and Iberian Exile Jewish communities showed no evidence for a narrow founder effect, which did however characterize the smaller and more remote Belmonte, Indian and the two Caucasus communities. The Indian and Ethiopian Jewish sample sets suggested local female introgression, while mtDNAs in all other communities studied belong to a well-characterized West Eurasian pool of maternal lineages. Absence of sub-Saharan African mtDNA lineages among the North African Jewish communities suggests negligible or low level of admixture with females of the host populations among whom the African haplogroup $(\mathrm{Hg}) \mathrm{L} 0$-L3 sub-clades variants are common. In contrast, the North African and Iberian Exile Jewish communities show influence of putative Iberian admixture as documented by mtDNA Hg HV0 variants. These findings highlight striking differences in the demographic history of the widespread Jewish Diaspora (Behar, et. al).

The reader's report for this peer-reviewed article has suggestions for the authors but what is of interest for our purposes is this remark that opens the review: "The topic is certainly of sufficient interest to a wider audience - but, of course, also to mtDNA specialists because of the wealth of information given." I would imagine that there are very few areas of mtDNA studies, with the exception perhaps of those dealing with early hominid, that have a "wider audience" beyond the field of scientific specialists. The 
genetics of the Jews or more broadly put, the origins of the Jewish people, is one such field. In fact, the results of these studies are even published in non-scientific journals and websites and just as was the case over one hundred years ago, Jewish newspapers the world over regularly carry stories on Jewish origins. All of this speaks to the ongoing widespread and undiminished interest in the subject (Lavender 2009).

\section{The Khazar Theory}

Aside from the Sephardic-Ashkenazic split the other anthroplogical discourse that emerged in the nineteenth century and one remains at the heart of discussions about the origins of various Jewish groups concerns the Jews of Eastern Europe. Only today, genetic testing plays an important role in such discourse. But so too does politics and culture and in ways no less crude than the nineteenth century descriptions produced above.

The issue turns on where and how blond and Asiatic elements made their way into a group that was thought to have been purely Semitic in origin. At the heart of such discussions was a Jewish physician and physical anthropologist from Southern Russia, named Samuel Weissenberg (1867-1928). In 1895 he published his study "The Jews of Southern Russia," for which he was awarded a gold medal by the Moscow Society for the Natural Sciences. All this is to say the serious study of race in the pre-genetic era was not the work of lunatics or racists (although there were some). It was the domain of serious and celebrated men of science. And Weissenberg was one of them.

In this study Weissenberg wished to establish the origins of Jewish settlement in Russia. His study was based on his medico-anthropological examination of some 1350 Jews in his home town of Elizavetgrad. Weissenberg then compared his figures to those 
derived from the same tests carried out on non-Jews by other anthropologists. This led him to reject the traditional, and still popular view, which holds that the bulk of Eastern European Jewry was formed out of those western Jews who began to migrate from Germany in an eastwardly direction in the wake of persecutions in the Middle Ages. According to Weissenberg, German Jewry had itself originally come from France, and it was inconceivable that the millions of Yiddish speaking Jews that existed in his day (approximately five million in 1897) could have originated in these tiny Franco-Jewish colonies (Jacobs 2005).

For Weissenberg, literary-historical documents provided unassailable evidence that the Jews had settled in Russia long before the eleventh century as was often claimed. Above all, it was the Khazar conversion of the eight century which proved for Weissenberg that both Jewish settlement in Eastern Europe was much older than previously thought, and that the Jews had early on achieved a position of considerable influence there. "How otherwise can one explain the conversion of the Khazars?," he asked (Weissenberg 1895: Morton 1954; Golden 2007). In arguing for the ancient rootedness and great importance of Russian Jewry, Weissenberg was making a claim that the Jews were an integral element on Russian soil. With a mature national consciousness, and exemplary tolerance, the Jewish community of the eighth century accepted and integrated thousands of Khazars into its ranks. When the Jewish Khazars were absorbed into the Kievan empire in the tenth century, the Jewish influence continued to live on after all traces of Khazar culture had vanished. The implication here is that Jewish culture in Russia predated Russian culture. (It is for this reason that Stalin banned Khazar studies). 
That a conversion to Judaism took place among the Khazars was and still is widely accepted. What is unclear is its dimensions. Was it just the elite or did it include the masses as well? (Brook 2009). But how had the first Jews, those that converted the Khazars, come to be in Russia in the first place? There were, according to Weissenberg, two possibilities. They had either come from the south, from the thriving Greek colonies on the Black sea, or from the east, through the Caucasus. Inscriptions and monuments in Crimea attested to Jewish settlement from the Byzantine empire in the early Christian centuries. But evidence also existed that proved Jewish settlement had taken place in the Caucasus prior to the destruction of the Second Temple. According to Weissenberg, a change in the privileged conditions which they enjoyed in Armenia led some Jews to migrate prior to the beginnings of the Christian era over the Caucasus into Southern Russia. The fact of this early settlement, and Khazar conversion, was of central importance in the debates over the origins of the Jewish types. As Weissenberg noted:

Anthropology and history must go hand in hand to solve the dark question of the origin of the Russian Jews....My opinion for the causes of the changes of types to be found among Southern Russian, and East European Jews in general is to be sought in the migration of Jewry over the Caucasus and the Russian steppes. Perhaps already in antiquity, intermixture took place during the migration, and the Judaization that occurred with the surrounding peoples, and the close contact with the pronounced short [round]-headed Caucasians, such as the Turkic Khazars, can explain the almost complete short-headedness and frequent Mongoloid features of the Jews. [For Mongoloid read Asiatic. JME] (Weissenberg 1895)

Weissenberg's pronouncement was meaningful. For having identified the Caucasus as the cradle of Jewish civilization in Europe, from which there emerged large numbers of Jews who eventually formed the nucleus of European Jewry, Weissenberg had, by implication, accorded the same exalted position to that mountainous region as 
had the father of modern anthropology, Blumenbach, who, as noted above, in 1795, declared the Caucuses as the racial cradle of the Europeans. Therefore, for Weissenberg, European Jews were intimately linked to Europeans by having been racially transformed by that intermixture that had taken place in the Caucasus. A further, and perhaps more significant lesson to be drawn from this, was that it was not Western European, but Eastern European Jews, with their noble past and culturally vital present who were, for Weissenberg, the authentic creators and bearers of the European Jewish tradition. Ashkenazic Jewry did not, therefore stem from those small Jewish communities in Germany but emerged in situ—in Eastern Europe.

Since Weissenberg's day and into our own, the Khazar hypothesis has been at the forefront of scientific discourse about Jewish origins. Peter Golden, perhaps the leading authority on the history of the Khazars, concludes that "the role of the Khazars in the shaping of East European Ashkenazic Jewry is periodically the subject of speculation. Judaized Khazars may have been one of the components of what became the largest Jewish community in the modern era, but it is very unlikely that they were a determinative element" (Yivo Encycolpedia). Nonetheless interest in the Khazars and those wishing for the hypothesis to be true, whether out of romantic attraction to the idea or out of political motivations continue their quest. (Khazaria.com)

While there is little historical consensus on the matter recent genetic testing provides some credence to support the Jewish-Khazar link. For example, the "KhazarDNA Project" run by the population geneticist, Eran Elhaik has recently concluded in a study entitled, "The Missing Link of Jewish European Ancestry: Contrasting the 
Rhineland and the Khazarian Hypotheses.” Rejecting the Rhineland hypothesis, the study concludes:

Recent sequencing of modern Caucasus populations prompted us to revisit the Khazarian Hypothesis and compare it with the Rhineland Hypothesis. We applied a wide range of population genetic analyses - including principal component, biogeographical origin, admixture, identity by descent, allele sharing distance, and uniparental analyses - to compare these two hypotheses. Our findings support the Khazarian Hypothesis and portray the European Jewish genome as a mosaic of Caucasus, European, and Semitic ancestries.... (Elhaik 2013).

The Elhaik article has been criticized by a team of geneticists elsewhere in this issue. While the job of the population geneticist is to either validate or invalidate the article's findings the job of the historian is to try and understand the possible cultural meanings or implications of the article (Discover Magazine Blog). I mentioned at the start of this discussion of the Khazars that the contemporary scientific work done on the Khazar theory is no less open to politicization than the work done in the pre-genetic era. The abovementioned article by Elhaik has occasioned lively online debate, for example, at the White Supremacist website Stormfront.org. (Stormfront). As one poster noted: "But the Khazarian theory says that Ashkenazi [sic] aren't even descendant [sic] of the original Jews (which they claim) but instead converts from Khazaria. This study supports this, pretty much proving that the majority of modern Jews have no biological ties to the land of Israel." The political intent of this poster at this particular site is self evident.

From a cultural point of view it is of significance that at the website khazaria.com, one finds a section entitled "Jewish Genetics: Abstracts and Summaries." This is a large "collection of abstracts and reviews of books, articles, and genetic studies" on Jewish origins and then goes on to claim: 
This section is the most comprehensive summary of Jewish genetic data. In recent years, advances in genetic technology and the broadening in scope of genetic studies to encompass more ethnic groups have allowed scientists to come to more accurate conclusions. Now that we have the benefit of more than a decade of comprehensive genetic testing of Jewish populations using modern techniques, we have finally come close to answering all the questions about Jewish ancestry. Part of the story is that Eastern European Jews have significant Eastern Mediterranean elements which manifest themselves in close relationships with Kurdish, Armenian, Palestinian Arab, Lebanese, Syrian, and Anatolian Turkish peoples. This is why the Y-DNA haplogroups J and E, which are typical of the Middle East, are so common among them. Jewish lineages from this region of the world derive from both the Levant and the Anatolia-Armenia region. At the same time, there are traces of European (including Northern Italian and Western Slavic or Eastern Slavic) and Khazar ancestry among European Jews. Many Greek and Roman women married Jewish men before conversion to Judaism was outlawed by the Roman Empire, and many of the Southern European ancestral lines in Ashkenazic families come from these marriages. Ethiopian Jews mostly descend from Ethiopian Africans who converted to Judaism, but may also be related to a lesser extent to Yemenite Jews. Yemenite Jews descend from Arabs and Israelites. North African Jewish and Kurdish Jewish paternal lineages come from Israelites. Jewish Y-DNA tends to come from the Middle East, and that studies that take into account mtDNA show that many Jewish populations are related to neighboring non-Jewish groups maternally. All existing studies fail to compare modern Jewish populations' DNA to ancient Judean DNA and medieval Khazarian DNA, but in the absence of old DNA, comparisons with living populations appear to be adequate to trace geographic roots.

The idea that Eastern European Jews "have significant Eastern Mediterranean elements," including "Palestinian Arab, Lebanese, Syrian, and Anatolian Turkish" among them is, if true, deeply unsettling for those with a political agenda for which the Khazar Hypothesis is far more useful. With subsections at khazaria.com on "Studies of Jewish Populations," "Studies of Cohens and Levites," "Studies on Jewish Genetic Diseases (with special attention on studies that help to confirm Jewish origins, relationships, and migrations)," and "Studies that Test the Potential Israelite Ancestry of Non-Jewish Populations," the website provides a wealth of information, both historical and scientific, 
on the subject of Jewish genetic makeup and history. Up-to-date and online since May 1995, the website is testament to an ongoing fascination with the biological history of the Jewish people.

While today's genetic studies look very different from eighteenth and nineteenth century race science what remains unchanged are some of the most fundamental questions about Jews; What are their origins? How is it that there is so much variation among them? Where do the different groups come from? What is the extent of mixing between Jews and non-Jews? Are Jews susceptible to certain medical disorders? These are questions that modern Jews (and non-Jews) have been pondering since the eighteenth century. These are not just questions of and for science. The fact that we are still trying to answer some or all of them means that they remain interesting and powerful and are as much about Jewish identity and culture as they are about science itself. 
Literature Cited

Hannaford, I. 1996. Race: A history of an idea in the west. Washington, D.C.: Woodrow Wilson Center Press.

Mühlmann, Wilhelm E. Geschichte der anthropologie. 1968. Frankfurt a.M., Bonn, Athenäum Verlag.

Mosse, Werner E. 1995. 'From ‘Schutzjuden' to 'Deutsche Staatsburger Jüdischen Glaubens': The long and bumpy road of Jewish emancipation in Germany" in Pierre Birnbaum and Ira Katznelson, eds. Paths of emancipation: Jews, states, and citizenship. Princeton: Princeton University Press, 59-93.

Hyman, Paula. The Jews of France 1998. Berkeley: University of California Press, 17-35.

Efron, John M. 1994. Defenders of the race: Jewish doctors and race science in fin-desiècle Europe. New Haven: Yale University Press, 13-32.

Blumenbach, Johann Friedrich. 1865. On the natural variety of mankind in Thomas Bendyshe, The anthropological treatises of Johann Friedrich Blumenbach London: Longman, Green, Longman, Roberts, \& Green, 209-210 and 264-266.

Blumenbach, On the Natural Variety of Mankind, 229-230 and 234.

Efron. 1994. Defenders of the race, 20-21.

Auerbach, Elias. 1907. “Die jüdische Rassenfrage," Archiv für Rassen- und Gesellschaftsbiologie 4: 332-361.

Hart, Mitchell B. 2000. Social science and the politics of modern Jewish identity. Stanford: Stanford University Press.

Judt, I. M., 1903. Die Juden als Rasse; eine Analyse aus dem Gebiete der Anthropologie. Berlin: Jüdischer Verlag.

Efron, John M. 2001. Medicine and the German Jews: A History. New Haven: Yale University Press.

Shtull-Trauring, Simcha. 1996. Letters from beyond the Sambatyon: the myth of the ten lost tribes. 1996. New York: Maxima New Media.

Parfitt, Tudor. 2000. Journey to the vanished city: the search for a lost tribe of Israel. New York: Vintage Books. 
Gonen, Rivka. 2002. The quest for the ten lost tribes of Israel: to the ends of the earth. Northvale, NJ: Jason Aronson Publishers.

Halkin, Hillel. 2002. Across the Sabbath river: in search of a lost tribe of Israel. 2002. New York: Houghton Mifflin Harcourt.

Brook, Kevin Alan. 2003. The Jews of Khazaria. Northvale, NJ: Jason Aronson Publishers, 2003.

Asa-El, Amotz . 2004. Diaspora and the lost tribes of Israel. Westport, CT: Hugh Lauter Levin Associates.

http://www.pbs.org/wgbh/nova/israel/losttribes.html

Hansen, Vaughn E. 2012 Israel's lost 10 tribes: migrations to Britain and USA. Springville, UT: Cedar Fort.

Ben-Dor Benite, Zvi. 2009. The ten lost tribes: a world history. New York: Oxford University Press

Howlett, Thomas Rosling. 2012. Anglo-Israel, the Jewish Problem ...: The Ten Lost Tribes of Israel Found and Identified in the Anglo-Saxon Race. the Jewish Problem Solved in the ... and Restoration of the Israelitish Nation. Charleston, SC: Nabu Press. The book was first published in 1892 in Philadelphia by Spangler \& Davis.

Auerbach, Elias. 1907b. "Bemerkungen zu Fishberg's Theorie über die Herkunft der Blonden Juden," Zeitschrift für Demographie Statistik der Juden, 3: 92-93.

Hart, Mitchell B., ed., 2011. Jews and Race: Writings on Identity and Difference, 18801940. Waltham, MA.: Brandeis University Press.

Alsberg, Moritz. 1891. Rassenmischung im Judentum. Hamburg: J.S. Richter.

Poliakov, Léon. 1977. The Aryan Myth: A History of Racist and Nationalist Ideas in Europe. New York: Meridian, 1977).

Gould, Stephen Jay. 1996. The Mismeasure of Man. New York: W.W. Norton.

Efron. 1994. Defenders of the Race, 58-90.

Jacobs, Joseph. 1891. Studies in Jewish Statistics: Social, Vital, and Anthropometric. London: D. Nutt, i-lxix.

Von Luschan, Felix. "Die anthropologische Stellung der Juden," 1892. Correspondenzblatt der deutschen Gesellschaft für Anthropologie, Ethnologie und Urgeschichte, 23: 94102. 
Jacobs, Joseph. “Are Jews Jews?,” 1899. Popular Science Monthly 55: 502-503.

Ripley, William Z. 1899. The Races of Europe: A Sociological Study. New York: D. Appelton, 368-400.

Jacobs, 1899. “Are Jews Jews?,” 507.

Ripley, The Races of Europe, 385-386.

Ripley, The Races of Europe, 388-389.

Ripley, The Races of Europe, 390.

Ripley, 1899. The Races of Europe, 394.

Weissenberg, Samuel. 1895. "Die südrussischen Juden: Eine anthropometrische Studie," Archiv für Anthropologie, 23: 567.

Jacobs. 1891. "On the Racial Characteristics of Modern Jews" in Studies in Jewish Statistics, xxxii.

Ripley. 1891. The Races of Europe, 395.

Andree, Richard. 1881. Zur Volkskunde der Juden. Bielefeld und Leipzig: Velhagen \& Klasing), 39 and 45.

Ripley. 1891. The Races of Europe, 396.

Efron, John M. forthcoming. Sephardic aesthetics and the Ashkenazic imagination: German Jewry in the age of emancipation (Indiana University Press).

Mosse, George L. 1996. The Image of Man: The Creation of Modern Masculinity. Oxford: Oxford University Press, 17-55.

Neubauer, Adolf. 1885. "Notes on the Race-Types of the Jews," Journal of the Royal Anthropological Institute of Great Britain and Ireland, 15: 19.

Fishberg, Maurice. The Jews: A Study of Race and Environment. New York: Walter Scott, 108-110.

See Behar, Doron., et. al., 2008. "Counting the Founders: The Matrilineal Genetic Ancestry of the Jewish Diaspora," PLoS ONE 3(4): e2062.

doi:10.1371/journal.pone.0002062 
Lavender, Abraham D. 2009. "DNA Origins and Current Consequences for Sephardi, Mizrahi, and Ashkenazi Males and Females: Latest Results from Medical, GeneologicalFamilial, and National-Ethnic Research," Journal for the Study of Sephardi \& Mizrahi Jewry 2: 99-129.

Jacobs, Neil G. 2005. Yiddish: A Linguistic Introduction. Cambridge: Cambridge University Press, 9-56.

Dunlop, Douglas Morton. 1954. History of the Jewish Khazars. Princeton: Princeton University Press.

Golden, Peter., ed. et. al., 2007. The World of the Khazars. Leiden: Brill.

Brook, Kevin Alan. 2009, 87-124.

Weissenberg. 1895. "Südrussischen Juden,” 578-579.

http://www.yivoencyclopedia.org/article.aspx/Khazaria (Accessed Jan 14, 2013).

The most comprehensive site dedicated to the subject is http://www.khazaria.com/

Elhaik, Eran. 2013. "The Missing Link of Jewish European Ancestry: Contrasting the Rhineland and the Khazarian Hypotheses," Genome Biology and Evolution 5: 61-74. The quotation is taken from the article's Abstract.

http://blogs.discovermagazine.com/gnxp/2012/08/ashkenazi-jews-are-probably-notdescended-from-the-khazars/\#.UPSNNYnjnXY (Accessed Jan 14, 2013).

http://www.stormfront.org/forum/t905535/ 